\title{
Catatan Editor mengenai edisi khusus "Tanggapan terhadap COVID-19": Kontribusi ilmu psikologi sosial terhadap situasi pandemi
}

\author{
Indra Yohanes Kiling1, Setiawati Intan Savitri' ${ }^{2}$, \& Rahkman Ardi ${ }^{\mathbf{3}}$ \\ ${ }_{1}$ Prodi Psikologi, Fakultas Kesehatan Masyarakat, Universitas Nusa Cendana, Kupang, NTT \\ ${ }^{2}$ Fakultas Psikologi, Universitas Mercu Buana, Jakarta, Jawa Barat \\ ${ }^{3}$ Fakultas Psikologi, Universitas Airlangga, Surabaya, Jawa Timur
}

Setelah 1 tahun 2 bulan sejak World Health Organization (WHO) mendeklarasikan pandemi coronavirus disease (COVID-19), sudah banyak aksi yang dilakukan berbagai pemangku kepentingan untuk meminimalisir dampak biologis, psikologis serta sosial yang dirasakan oleh masyarakat. Vaksinasi sebagai salah satu respon utama untuk pandemi COVID-19 terus dilakukan, walaupun masih terlihat ketimpangan dalam pelaksanaannya. Sebuah laporan dari jurnal Nature Human Behaviour (Mathieu dkk., 2021) menyebutkan bahwa terhitung tanggal 7 April 2021, sebanyak 710 juta dosis penyuntikan vaksin sudah dilakukan secara global di 169 negara (dari 221 negara yang terdampak). Namun, hanya lima persen (5\%) dari populasi dunia yang telah menerima setidaknya satu dosis vaksin dan perkembangan pelaksanaan vaksinasi di negara berpendapatan rendah berjalan lambat dibandingkan dengan kebanyakan negara berpendapatan tinggi dan menengah.

Pada situasi dimana pelaksanaan vaksinasi berjalan lambat, intervensi pembatasan sosial merupakan intervensi nonmedis yang dilakukan di hampir semua negara yang terdampak. Studi lain dari Nature Human Behaviour (Huang dkk., 2021) menyebutkan bahwa pembatasan sosial berhasil mengendalikan angka infeksi COVID-19 pada kota-kota dengan kepadatan penduduk yang tinggi di Cina. Meskipun berhasil, namun studi dari Nature Communications mengungkapkan bahwa pembatasan sosial juga memiliki potensi dampak pada ketimpangan sosial seperti yang dirasakan masyarakat miskin di Chili yang merasakan beban sosial dan ekonomi yang lebih besar dari masyarakat yang lebih mampu (Gozzi dkk., 2021).

Pelaksanaan vaksinasi di Indonesia masih membutuhkan usaha lebih lanjut karena pada 16 Mei 2021, kurang lebih 22 juta penduduk yang sudah divaksinasi dari target 181 juta penduduk. Survei dari Kementerian Kesehatan menyebutkan bahwa sebanyak 35\% masyarakat Indonesia merasa ragu dan menolak vaksin COVID-19. Respon masyarakat pada pembatasan sosial di Indonesia sendiri cenderung semakin menuju ke arah penolakan dengan contoh fenomena yang terjadi pada hari raya Idul Fitri tahun 2021 (covid19.go.id, 2021). Keberhasilan Indonesia untuk menerapkan intervensi medis dan non-medis untuk menangani pandemi salah satunya dipengaruhi oleh perilaku dan keadaan psikologis baik secara individual maupun kolektif. Pemahaman terhadap dinamika psikologis masyarakat Indonesia akan membantu pemangku kepentingan untuk menyusun strategi pelaksanaan intervensi yang lebih baik.

Dalam edisi ini, Jurnal Psikologi Sosial (JPS) melaporkan lima naskah yang menelaah fenomena-fenomena sosial yang terkait dengan reaksi psikologis orang Indonesia pada pandemi COVID-19. Naskah Adinugroho dan Simanjuntak (2021) memberi pencerahan bahwa pemerintah Indonesia perlu memberi perhatian dalam meningkatkan dan menegaskan nilai integritas dan kebajikan sebagai upaya untuk meningkatkan kepercayaan dan optimisme masyarakat dalam menghadapi pandemi. Naskah Andayani (2021) melaporkan hasil survei dari 587 individu di Indonesia yang menggunakan media sosial sebagai sumber utama untuk memperoleh informasi terkait pembatasan sosial yang mengisyaratkan pentingnya untuk mewaspadai potensi berita hoaks. Naskah ini juga melaporkan beberapa dampak negatif yang dirasakan dari kebijakan pembatasan sosial seperti kesulitan dalam pemenuhan kebutuhan pokok hingga menurunnya kualitas interaksi sosial.

Perilaku individu Indonesia dalam menaati intervensi pemerintah terkait perilaku pencegahan infeksi virus dikupas dari perspektif personsituation theory oleh Kurt Lewin dalam Narhetali (2021). Telaah ini dapat memberikan perspektif baru bagi masyarakat untuk lebih mematuhi kebijakan pemerintah baik intervensi medis maupun non medis. Selanjutnya naskah Shadiqi, Hariati, Hasan, I'anah, dan Al Istiqomah (2021) mendiskusikan penjelasan psikologis dari fenomena panic buying yang dapat membantu pembuat kebijakan dalam memformulaskan langkah- 
langkah intervensi dan prevensi dari panic buying yang dapat terjadi pada saat pandemi atau situasi kebencanaan/darurat lainnya.

Naskah terakhir dari Rahardjo, Qomariyah, Mulyani, dan Andriani (2021) menjelaskan lebih lanjut fenomena social media fatigue pada mahasiswa yang ditinjau dari berbagai keadaan psikologis seperti kecemasan, kepribadian neuroticism, invasion of life, serta kelebihan informasi sebagai anteseden utama. Beberapa pola yang teridentifikasi melalui uji statistik dapat membantu pembaca untuk lebih memahami tren dari kelelahan mahasiswa dalam menggunakan media sosial di kala pandemi dan bagaimana menangani isu psikologis terkait penggunaan media sosial.

Pembatasan sosial memicu banyak reaksi psikologis yang akhirnya dapat berpengaruh pada kesiapan masyarakat dalam menerima vaksinasi. Perhatian khusus perlu ditujukan pada pelaksanaan intervensi nonmedis sehingga dapat menunjang pelaksanaan intervensi medis. Jurnal Psikologi Sosial berharap naskah-naskah ini dapat berkontribusi pada pengembangan keilmuan dan praktik psikologi sosial di Indonesia, pada khususnya dalam konteks pandemi global, sehingga Indonesia dapat lebih siap untuk menghadapi keadaan yang serupa jika terjadi di masa depan serta memiliki strategi efektif untuk menerima dan mengelola kebiasaan baru.

\section{Daftar Pustaka}

Adinugroho, I., \& Simanjuntak, R. (2021). Political trust on Covid-19 handling as predictor towards optimism on the new normal situation: Integrity and benevolence rather than competence. Jurnal Psikologi Sosial. Retrieved from http://jps.ui.ac.id/index.php/jps/article/ view/266

Andayani, T. (2021). Sumber informasi serta dampak penerapan pembatasan sosial dan fisik pada masa pandemi COVID-19: Studi eksploratif di Indonesia. Jurnal Psikologi Sosial. Retrieved from http://jps.ui.ac.id/index.php/jps/article/ view/229

Covid19.go.id (2021). Survei penerimaan vaksin COVID-19 di Indonesia. https://covid19.go.id/storage/app/media /Hasil\%20Kajian/2020/November/vacci ne-acceptance-survey-id-12-112020final.pdf

Gozzi, N., Tizzoni, M., Chinazzi, M. et al. Estimating the effect of social inequalities on the mitigation of COVID-19 across communities in Santiago de Chile. Nat Commun 12, 2429 (2021). https://doi.org/10.1038/s41467-02122601-6

Huang, B., Wang, J., Cai, J. et al. Integrated vaccination and physical distancing interventions to prevent future COVID-19 waves in Chinese cities. Nat Hum Behav (2021). https://doi.org/10.1038/s41562021-01063-2

Mathieu, E., Ritchie, H., Ortiz-Ospina, E., Roser, M., Hasell, J., Appel, C., Giattino, C., \& Rodes-Guirao, L. (2021). A global database of COVID-19 vaccinations. Nature Human Behaviour. https://doi.org/10.1038/s41562-02101122-8

Narhetali, E. (2021). COVID-19 pandemic through the lens of person-situation interaction. Jurnal Psikologi Sosial. Retrieved from http://jps.ui.ac.id/index.php/jps/article/ view/230

Petterson, H., Manley, B., \& Hernandez, S. (24 Agustus, 2020). Tracking coronavirus' global spread. Retrieved from: https://edition.cnn.com/interactive/2020 /health/coronavirus-maps-and-cases/

Rajkumar, R. P. (2020). COVID-19 and mental health: A review of the existing literature. Asian journal of psychiatry, 102066. https://doi.org/10.1016/j.ajp.2020.1020 66

Rahardjo, W., Qomariyah, N., Mulyani, I., \& Andriani, I. (2021). Social media fatigue pada mahasiswa di masa pandemi COVID19: Peran neurotisisme, kelebihan informasi, invasion of life, kecemasan, dan jenis kelamin. Jurnal Psikologi Sosial. Retrieved from http://jps.ui.ac.id/index.php/jps/article/ view/220

Shadiqi, M. A., Hariati, R., Hasan, K. F. A., I'anah, N., \& Al Istiqomah, W. (2021). Panic buying pada pandemi COVID-19: Telaah literatur dari perspektif psikologi. Jurnal Psikologi Sosial. Retrieved from http://jps.ui.ac.id/index.php/jps/article/ view/221

Van Bavel, J. J., Baicker, K., Boggio, P. S., Capraro, V., Cichocka, A., Cikara, M., ... \& Drury, J. (2020). Using social and behavioural science to support COVID-19 pandemic response. Nature Human Behaviour, 1-12. https://doi.org/10.1038/s41562-0200884-z 